7. Cukanova, G. O. (2013). Suchasne vulychne grafiti jak forma social'noi' reklamy [Modern street graffiti as a form of social advertising]. Osvita regionu, 1.

8. Shylo, O. V. (2016). Monurmental'ne mystectvo i strit-art v suchasnomu mis'komu prostori [Monumental art and street art in a modern

A. O. Batenko, a First-year Master's Student

Taras Shevchenko National University of Kyiv,

60, Volodymyrska Street, Kyiv, 01033, Ukraine urban space]. Naukovyj visnyk budivnyctva, 2, 74-78. Retrieved from http://nbuv.gov.ua/UJRN/Nvb_2016_2_18

Надійшла до редколегії 13.10.2020

\title{
MURALART AS A COMPONENT OF THE CULTURAL SPACE OF THE CITY
}

The aim of the article is to define the role of mural art as a part of street art in the context of the cultural urban space. Identification of mural art in cities, its transformation depending on the place of creation and changes in the perception of the viewer requires needs research that is more detailed. A lot of people do not distinguish between concepts in street art; do not understand the artistic value of murals. Therefore, it is useful to show all functions, which murals can have. The quantity and quality of murals in the urban space affects its reputation, culture, development trends. That is, murals can both spoil urban visions and aestheticize them. Murals often engine enrichment of human consciousness, because artists raise important social issues, motivate the viewer to think. They try to turn the city into a large gallery, to influence people who involuntarily become spectators and connoisseurs of street art. It is also appropriate to explore the trends of Ukrainian muralism in the urban space. After all, street art has become very popular in Ukraine, as evidenced we can see various thematic festivals and competitions. The research methodology involves an interdisciplinary approach, analysis of scientific works of cultural and art history, review of thematic media and creative work of street artists to determine the characteristics and purposes of their activities. The works of modern Ukrainian researchers who study the issues of the cultural space of the city, mural art and street art in general are involved. The scientific novelty lies in the study of the influence of mural art on personal perception on drawing attention to socio-political problems in the urban context. On the example of the analysis of works of world street artists the tendency to social and educational function of murals, instead of simply aesthetic, is traced. The practical significance of the study is to emphasize that murals have artistic value, a unique semantic message, and are not just a means of aestheticization. The article can be useful for specialists in culturology, history, art history, architecture and for artists.

Key words: city, mural art, cultural space, street art, urban studies.

А. О. Батенко, студ. 1-го курса магистратуры

Киевский национальный университет имени Тараса Шевченко,

ул. Владимирская, 60, г. Киев, 01033, Украина

\section{МУРАЛ-АРТ КАК СОСТАВЛЯЮЩАЯ КУЛЬТУРНОГО ПРОСТРАНСТВА ГОРОДА}

Целью статьи является определение роли мурал-арта как течения уличного искусства в контексте культурного пространства города. Методика исследования предполагает привлечение междисциплинарного подхода, анализ научных работ культурологического и искусствоведческого направления, обзор тематических медиа и творчества уличных художников для определения характерных черт и целей их деятельности. Привлекаются труды современных украинских исследователей, изучающих вопросы культурного пространства города, мурал-арта и уличного искусства в целом. Научная новизна заключается в исследовании влияния мурал-арта на личностное восприятие и на привлечение внимания к социально-политическим проблемам в контексте города. Практическое значение исследования связано с акцентированием на том, что настенные картины на улицах имеют художественную ценность, уникальный смысловой посыл, а не являются только средством эстетизации.

Ключевые слова: город, мурал-арт, культурное пространство, уличное искусство, урбанистика.

удк 786.2

М.-М. В. Любива, студ. 4-го курсу Київський національний університет імені Тараса Шевченка, вул. Володимирська, 60, м. Київ, 01033, Україна messalina1856@ukr.net

\section{РУХ ІСТОРИЧНО ПОІНФОРМОВАНОГО ВИКОНАВСТВА В КОНТЕКСТІ КУЛЬТУРИ ХX-XXI СТОЛІТТЯ}

За останнє століття з'явилися нові музичні форми та виконавські практики, де наявний синтез спадщини багатьох стильових епох. Сучасні тенденції у виконавській творчості можна умовно поділити на три глобальні самостійні напрями - актуалізація, автентизм і авангард. Спостерігається утвердження нової парадигми, яка полягає у підвищенні ролі інтелектуального начала, у прагненні до вивчення музичного твору в контексті епохи, в очищенні традицій виконання від пізніших нашарувань. Виконавський тип автентичного напряму ставить завдання максимально точно відповідати уявленням композиторів минулого, відтворювати прийняті в різні історичні часи норми і традиції. Через те, що людина усвідомлює втрату своєї цілісності, традиційні форми мистецтва зазнають трансформацій та руйнацій, які викликали потребу звернення до культури бароко. Рецепція культури бароко сприяє відновленню культурної ідентичності, застерігає від полікультурної фрагментарності, створює умови для налагодження зв'язків між культурними епохами. Естетика бароко перетворюється на один із визначальних маркерів масової культури.

Ключові слова: музика, культура, історично поінформоване виконавство, автентизм, інтерпретація.

Постановка проблеми. 3 XX століття інтерпретація стає одним з центральних понять в культурі і науці, а проблема трактування активно розробляється в фрілософії та естетиці. Епоха постмодерну висуває нові вимоги до музичного мистецтва: прагнення до справжності, перетворення історичного минулого в дійсну сучасність. Спостерігається утвердження нової парадигми, яка полягає в підвищенні ролі інтелектуального начала, у прагненні до вивчення музичного твору в контексті епохи. Такі тенденції поступово встановлюються у вітчизняній музичній культурі, а отже, потребують висвітлення.
Аналіз досліджень і публікацій. Питання інтерпретації підіймалося у працях О.Шпенглера [5] та Г.-Г. Гадамера [1]. Характерним рисам барокової опери та ії актуалізації у вітчизняному музичному просторі присвячена робота Ж. Закрасняної [3]. Т. Гуменюк та Т. Кривошея досліджують переосмислення барокової музики та застосування законів автентизму у нових постановках барокових опер в Україні [2]. Сучасна інтерпретація барокової опери українськими митцями досліджується у роботі Н. Кречко [4]. 
Мета статті. Метою статті $€$ комплексне вивчення процесу формування та розвитку напрямку автентичного музичного виконавства в контексті культурних процесів XX-XXI ст. Дана мета передбачає визначення передумов виникнення руху, розкриття теоретичного підґрунтя, пов'язаного з формуванням історично поінформованого виконавства, висвітлення специфіки становлення руху в західноєвропейському та українському культурному просторі.

Виклад основного матеріалу дослідження. Герменевтичний метод вважається універсальним методом пізнання всієї гуманітарної сфери, адже предметом вивчення герменевтики $€$ текст, а метою - його розуміння. Оскільки для музиканта-виконавця авторський нотний текст $€$ вихідною умовою здійснення інтерпретації, то до музично-виконавського трактування герменевтичний метод $є$ цілком застосовним. Основи фрілософської герменевтики заклав Г.- Г. Гадамер. Дослідник бачить завданням герменевтики не тільки відтворення авторського тексту, але і можливість подальшого його розвитку, оскільки, на його думку, кожен новий інтерпретатор створює нові смисли, а отже, і новий текст. Гадамер стверджує, що в процесі інтерпретації дослідник вступає в активну взаємодію з текстом, в ході якої обидва учасники діалогу в однаковій мірі неминуче впливають один на одного. При цьому зрозумілими можуть стати тільки ті тексти, в яких можна побачити "живий" сучасний зміст.

Натомість О. Шпенглер заперечує пізнаваність однієї культури представниками іншої і зазначає, що різні культури не $є$ проникними одна для одної. Виходить, що людина пізнішої культури не здатна адекватно уявити себе індивідом минулої культури і не може зрозуміти хід його думок і дій. 3 такої ж позиції розглядає буття людини екзистенціалізм, говорячи про іїі історичність, зануреність в сьогодення, залежність не тільки майбутнього, а й минулого від теперішнього. Неупередженість при розгляді історії неможлива, об'єктивність історична, вона прямо відображає ту позицію в історії, з якої дослідник намагається відтворити минуле. На позиції взаємної непроникності культур також стоїть М. Гайдеґґер. Єдино можливим наближенням до іншої культури фрілософ вважає самостійне і повторюване у власній історії ії осмислення.

Розглядаючи виконавський стиль як історичне явище, можна встановити, що кожна історична епоха породжувала характерні для неї виконавські течії. Так, в епоху класицизму викристалізувався стиль виконання, строго відповідний естетичним уявленням того часу. Піднесеність поєднувалася в ньому з лаконізмом виразних засобів, чуттєве начало підпорядковувалося інтелекту, пристрасність мала відтінок інтелектуалізованої суворої патетики. У цей період чітко позначається новий тип музиканта-практика - універсального художника, що володіє багатосторонніми знаннями і навичками. В одній особі зливаються виконавець і творець музики, імпровізація знову стає основою виконавської майстерності. Світське музикування здійснюється в цей час в обраному колі слухачів, що забезпечує тісний контакт виконавця і слухача, їх інтимне співпереживання. Цей період відзначений також посиленням у виконавстві елементів суб'єктивізму і розвитком віртуозності.

У романтичну епоху відбувся докорінний поворот виконавського стилю, що наповнився палкістю, захопленістю, чуттєвою екзальтацією. Мистецтво XIX століття відрізняється прагненням композиторів до точного запису нотного тексту і фіксації виконавських вказівок. У цей час поступово приходить до занепаду мистецтво імпровізації.
Нарешті, у другій половині XIX століття разом з розквітом реалізму невід'ємними якостями виконавства стали об'єктивність, психологізм, мистецтво художнього перевтілення. Історія розвитку суспільства приводить до демократизації музичного життя, до переважання публічних концертів і театральних вистав. XIX століття відзначене поділом праці композитора і виконавця, поширенням типу виконавця-віртуоза, поступовим формуванням нового типу виконавця-інтерпретатора, поглибленням інтересу публіки до серйозного, ідейнозмістовного мистецтва.

В останнє сторіччя в царині музичного виконавства відбувається ряд процесів. Наявна експансія масової музичної культури у другій половині $\mathrm{XX}$ століття і пов'язаних із нею нових форм музичного театру і вистав. Можна прослідкувати розвиток сучасної виконавської практики в царині академічної музичної культури, що спирається на традиції класичного і романтичного мистецтва з урахуванням слухового і психологічного досвіду сучасної аудиторії. Також відбувається поширення автентичного виконавства, що свідчить про історизм сучасної виконавської культури, про синтезування в ній спадщини багатьох стильових епох.

Систематизуючи сучасні тенденції у виконавській творчості, можна умовно виділити три глобальні самостійні напрямки - актуалізація, автентизм і авангард. Їх відмінності визначають дві складові: музичний матеріал і інструментарій, під яким розуміється не тільки безперервне якісне і кількісне оновлення інструментів, але і характер музикування.

У другій половині XX століття у виконавському мистецтві зросла актуальність стильової проблематики, зокрема питання відповідності оригіналу виконавських інтерпретацій, що були створені і виконувалися в різні епохи та історичні періоди представниками різних національних і регіональних шкіл. Виконавський тип автентичного напряму ставить завдання максимально точно відповідати уявленням композиторів минулого, відтворювати прийняті в різні історичні часи норми і традиції. Прагнучи максимально точно "воскресити" авторський текст, багато автентистів займаються науковими дослідженнями: намагаються не тільки відтворити всі деталі нотного тексту на основі ретельного вивчення текстологічних джерел, але і відобразити тонкощі стилістики виконання.

Датою виникнення історичного виконавства вважається 11 березня 1829 року, коли під керівництвом молодого композитора Ф. Мендельсона вперше після столітньої перерви в Берліні прозвучали "Страсті за Матвієм" Й. С. Баха. До цього твори Баха та Генделя використовувались в якості учбового матеріалу для формування композиторських навиків. Оригінальна партитура "Страстей" була радикально скорочена для кращого сприйняття публікою, а також переінструментована через відсутність відповідного епосі інструментарію.

Твори Й. С. Баха, Г. Ф. Генделя, В.А.Моцарта вивчались у консерваторіях, що почали зароджуватись саме у XIX ст., як такі, що своєю простотою з точки зору композиції покажуть розвиток музики та сучасну естетичну позицію. Старі твори бралися за зразок для наслідування та були відправною точкою. Прикладом першої в історії рефлексії минулих епох як стилістичних цілісностей є "Історична" симфонія Луї Шпора (1839). Симфонія має 4 частини, кожна з яких відповідає періоду в історії музики: 1 частина - "Бахівськогенделівський період" (1720), 2 частина - "Гайдномоцартівський" (1780), 3 частина - "Бетховенський" (1810), 4 частина - "Наші дні" (1840). У симфонії Л. Шпор відтворює не стилістику творів цих авторів, а естетику їх часів (феномен полістилістики), намагається 
схопити минуле з точки зору естетики періоду. 3 XIX ст. інтерес до музики минулого зростає, а в кінці століття в концертній програмі кількість сучасних творів дорівнює кількості творів минулих епох. Ініціаторами історичних концертів були композитори Ф. Ліст, А. Рубінштейн ("Серія історичних концертів") та інші. 3 того часу помітною $€$ тенденція до систематизації музичного матеріалу.

Однією з перших праць, що стосуються питань прочитання та виконання старовинних творів, є праця музикознавця, родоначальника руху автентичного виконавства Арнольда Долмеча "Інтерпретація музики XVII i XVIII століть, за матеріалами сучасників". Праця А. Долмеча припадає на роки Першої світової війни, 3 часів якої мав місце розкол в композиції - спостерігалося як наслідування старого як гаранта стабільності у світі, що руйнується, так і створення нового. У концертній програмі тих часів переважає виконання зразків минулого, що відображає загальну тенденцію до ідеалізації, романтизації минулого, зокрема XIX століття, у таких видах мистецтва, як література та архітектура. Завдяки діяльності Долмеча історичне виконавство швидко вийшло за межі Великої Британії. Внесок у розробку теоретичної бази напрямку зробив німецький музикознавець Карл Дітріх Арнольд Шерінг. Значне місце у спадщині Шерінга відведено дослідженням старовинної музики, особливо Й. С. Баха. Його монографія "Виконавська практика старовинної музики" (1931) містить гіпотези й аргументи, актуальні для автентичного виконавства і в наш час.

Підсумовуючи досягнення автентичного виконавства першої половини XX ст., можна відмітити такі тенденції: 3 виконавських навичок інтерпретатори старовинної музики опановували розшифровку цифрованого басу, корегували склад ансамблів, обираючи інструментарій та кількість виконавців, практикували вміння імпровізації та вірної розшифровки орнаментики. Удосконалювався відбір засобів виразності - штрихи, типи артикуляції, відповідність між динамікою та темпом. За тих часів інструментарій також набував якісних змін: мали місце перші спроби реконструкції старовинних інструментів, йшов пошук оригінальних інструментів, вивчалися висоти строїв, темперація.

Серед прибічників автентизму у другій половині XX ст. були такі музиканти, як Н. Арнонкур, Г. Леонхардт, Ф. Брюгген, брати Кьойкен, Ф. Херревеге, Дж. Е. Гардінер, К. Хогвуд та багато інших. У їхній діяльності проявився дещо інший підхід до інтерпретації творів XVII-XVIII ст., що виразився у прагненні більш точного прочитання уртекстів, очищенні оригіналів від редакційних нашарувань (штрихи, динамічні вказівки, мелізматика тощо), відтворенні загублених фрагментів та деталей існуючих уртекстів. Трансформація в автентичному виконавстві, що спостерігається в останній третині XX - на початку XXI ст., стосується інструментарію з'являється велика кількість якісних копій старовинних інструментів та реконструкцій, що дає змогу обирати інструмент задля дотримання якомога більшого наближення до оригіналу. Деталізації та уточнення зазнали засоби виразності та їх використання відповідно до індивідуальних стилів, течій, напрямків, шкіл. Можливою стала реалізація старовинних музичних творів у залах, що відповідали тій епосі та виконавській ситуації.

У відношенні музичних інструментів було б невірним вважати їх зміну прикладом однозначно прогресивного історичного розвитку, коли кожна нова епоха, відмовляючись в силу своїх потреб від деяких застарілих поглядів попереднього часу, неодмінно цим "удосконалюється". Тоді ми цілком усвідомлюємо, що історія музики завжди була не тільки історією придбань, а й історією втрат. Вагомим фрактором при виконанні барокової музики $€$ розуміння і вибір правильного темпу, зважаючи на те, що в ту епоху в нотних текстах часто були відсутні авторські темпові вказівки. I саме вибір того чи іншого темпу ставав для виконавця одним з найголовніших засобів для передачі необхідного афекту.

На відміну від західноєвропейського простору, де напрямок історично поінформованого виконавства давно став одним з ключових у музичній культурі, для вітчизняного характерний етап становлення. Інтерес до даного напрямку в українському середовищі підготовлений рядом подій, які відбуваються у закордонній практиці. Зокрема, важливу роль у розвитку та популяризації автентичного виконавства відіграють міжнародні фестивалі старовинної музики, серед яких IHсбрукський фестиваль давньої музики, Фестиваль барокової музики в Амброні, Бостонський фестиваль давньої музики, Oude Muziek в Утрехті, Бонський фестиваль барокової опери, Лондонський фестиваль барокової музики, фестиваль "Earlymusic" у СанктПетербурзі, Брайтонський фестиваль старовинної музики, фрестиваль "Vaasa Baroque" у Фінляндії, фестиваль барочної музики у Валлетті (Мальта), фестиваль барокової музики Barocco Nights (Москва), фестиваль історичного виконавства "Антикваріум". У вересні 2020 року перший фестиваль барокової опери відбудеться у Байройті (Німеччина), що відомий Вагнерівським фестивалем з кінця XIX ст. Місце проведення фестивалю - Маркграфський оперний театр середини XVIII ст., що входить до списку Всесвітньої спадщини ЮНЕСКО. Програма першого фестивалю включатиме концерти та дві постановки барокових опер.

Інтерес до старовинної, зокрема барокової, музики пожвавився в осередках музичного життя України, про що свідчить ряд проєктів, пов'язаних із практиками історично поінформованого виконавства. Фестиваль барокової музики "Italia Festival Barocco" - спільний проєкт Італії та України під художнім керівництвом Нансі Мілезіс Романо. Фестиваль давньої музики у Львові один з українських інтернаціональних фестивалів, що на професійному рівні представляє давню вокальну та інструментальну музику різних європейських країн. Традиції автентичного виконавства підтримуються та пропагуються незалежною мистецькою платформою Open Opera Ukraine. Діяльність платфрорми спрямована на формування нової культури музичного сприйняття широкою аудиторією інтелектуального продукту через сучасні оперні постановки, сприяння професіоналізації та популяризації жанру опери в Україні. Місією проєкту Open Opera Ukraine є просування погляду на класичну музику як на інструмент комунікації, розуміння, самоідентифікації та критичного аналізу сучасності за допомогою створення якісних художніх проєктів, підтримки молодих талантів в Україні, надання широкій аудиторії доступу до високоякісних музичних продуктів. Реалізації цілей проєкту також сприяє звернення у постановках до актуальних мистецьких та суспільних трендів. За традиціями історично поінформованого виконавства на базі проєкту поставлені опери "Дідона та Еней" Г. Перселла та "Ацис і Галатея" Г. Генделя. Сучасна інтерпретація барокових опер стала важливим кроком на шляху до усвідомлення нових можливостей їх розуміння, переосмислення ключових епізодів та подальших перспектив актуалізації барокової музики у вітчизняному просторі. Постановки-рецепції Open Opera Ukraine $€$ потужним механізмом самоідентифікації і гуманізації в глобальному полікультурному світі та створюють необхідне тло для розвитку культурномистецької сфери в Україні. 
Висновок. Мистецька спадщина минулого займає в сучасній музичній культурі одне з найважливіших місць. Свідченнями цьому є широкий інтерес до різних жанрів давньої музики, імен, історичних фрактів; процес ії відродження, який охопив концертну і театрально-сценічну практику; поява нових виконавських колективів відповідного профрілю; неспадаючий попит на аудіозаписи; дискусії про те, як повинна сьогодні звучати музика давно минулих часів, про автентичність у музиці, про принципи художньо-історичної реконструкції. Інтерес до вирішення проблем виконавської практики співу барокового репертуару виражається в проведенні міжнародних симпозіумів, наукових конференцій, творчих майстерень для молодих виконавців.

Актуалізація музики минулих епох - природна потреба культури, що стрімко розвивається. У виконавському мистецтві вона спонукає до пошуку нових індивідуальних підходів, свіжих трактувань, адекватних своєму часу. Тому історизм мислення в сучасній культурі висунув на авансцену новий виконавський напрямок - автентичний, що вимагає інших виконавських та оціночних підходів.

Мета автентичного виконання - надтворча, що вимагає не тільки синтезу знань і уяви, але і сміливості в руйнуванні сформованих стереотипів. Моделюючи передбачуваний характер музикування, адекватний часу і місцю створення, призначенню твору, виконавець вводить слухача в реконструйований ним духовний світ. Надзавданням автентичного виконавства стає звіль- нення від штампів і стереотипів, повернення до початкової природи музики.

\section{СПИСОК ВИКОРИСТАНИХ ДЖЕРЕЛ}

1. Гадамер Г.-Г. Истина и метод: Основы философской герменевтики / Г.-Г. Гадамер. - М. : Прогресс, 1988. - 704 с.

2. Гуменюк Т. Рецепція "Perola barocca" (дивовижна перлина) в сучасному художньому просторі України / Т. Гуменюк, Т. Кривошея // Вісн. Національної академії керівних кадрів культури і мистецтв. - 2019. № 1. - С. 20-25.

3. Закрасняна Ж. М. Барокова опера та її актуалізація в сучасній музичній культурі / Ж. М. Закрасняна // Молодий вчений. - 2017. № 10.- C. 268-271.

4. Кречко Н. М. Сучасна інтерпретація опери Генрі Перселла "Дідона та Еней": українські реалії / Н.М.Кречко, Н.О.Якобенчук, О. Ю. Грицюк // Молодий вчений. - 2017. - № 11. - С. 579-582.

5. Шпенглер О. Закат Европы. Очерки морфологии мировой истории. Всемирно-исторические перспективы ; пер. с нем. и примеч. И. И. Маханькова / О. Шпенглер. - М. : Мысль, 1998. - 606 с.

\section{REFERENCES}

1. Gadamer, H.-G. (1988). Truth and Method. Moskow, Progress (In Russian)

2. Gumenjuk, T., Krivosheja, T. (2019). Recepcija "Perola barocca" (divovizhna perlina) v suchasnomu hudozhn'omu prostori Ukraïni [Reception "Perola barocca" (amazing pearl) in the modern art space of Ukraine]. Visnik Nacional'noï akademiï kerivnih kadriv kul'turi i mistectv, № 1, 20-25.

3. Zakrasnjana, Zh. M. (2017). Barokova opera ta iï aktualizacija v suchasnij muzichnij kul'turi [Baroque Opera and its actualization in modern musical culture]. Molodij vchenij. № 10, 268-271.

4. Krechko, N. M., Jakobenchuk, N. O,. Gricjuk O. Ju. (2017). Suchasna interpretacija operi Genri Persella "Didona ta Enej": ukraïns'ki realii [Modern interpretation of Henry Purcell's Opera Dido and Aeneas: Ukrainian realities]. Molodij vchenij, № 11, 579-582.

5. Spengler, O. (1998). Decline of the West. Moskow, Mysl' (In Russian)

Надійшла до редколегії 05.09.20

M-M. V. Ljubiva, 4th year student

Taras Shevchenko National University of Kyiv,

60, Volodymyrska Street, Kyiv, 01033, Ukraine

\section{THE MOVEMENT OF HISTORICALLY INFORMED PERFORMANCE IN THE CONTEXT OF THE CULTURE OF THE XX-XXI CENTURY}

The hermeneutical method is the basis for performing interpretation, because the author's musical text is the initial condition for its implementation. Over the last century, new musical forms and performing practices have emerged, where there is a synthesis of the heritage of many stylistic eras. Modern trends in performance art can be divided into three global independent areas - actualization, authenticity and avantgarde. The orientation in modern performance is directed both at the historical authenticity of the performance and at the questions of the subjective potency of musical creativity. There is an affirmation of a new paradigm, which consists in increasing the role of the intellectual principle, in striving to study a musical work in the context of the epoch that created it, in clearing the traditions of performance from later layers. Due to the growing interest of musicians in Renaissance and Baroque music, the number of soloists and groups performing Western European works written before the middle of the XVIII century is increasing. Over the course of the century, there has been a change in the status of authentic performance from individual to universal and social, because it not only organizes the experience of the community of musicians, but also forms the consciousness of a whole generation of culture.

Due to the fact that a person is aware of the loss of the integrity, traditional art forms undergo transformations and destruction, which caused the need to appeal to the Baroque culture. The reception of the Baroque culture promotes the restoration of cultural identity, warns against multicultural fragmentation, and creates conditions for establishing links between cultural eras. The Baroque aesthetic is becoming one of the defining markers of popular culture.

Attempts to adequately reproduce musical impressions of past eras among performers and interest in them among the public is a significant characteristic of modern society. A comprehensive study of authentism as a direction allows us to understand the context and functions of music for the cultural types of that time.

Key words: music, culture, historically informed performance, authentism, interpretation.

М.-М. В. Любивая, студ. 4 курса

Киевский национальный университет имени Тараса Шевченко,

ул. Владимирская, 60, г. Киев, 01033, Украина

\section{ДВИЖЕНИЕ ИСТОРИЧЕСКИ ИНФОРМИРОВАННОГО ИСПОЛНИТЕЛЬСТВА} В КОНТЕКСТЕ КУЛЬТУРЫ XX-XXI ВЕКА

За последнее столетие появились новые музыкальные формы и исполнительские практики, для которых характерен синтез наследия многих стилевых эпох. Современные тенденции в исполнительском творчестве можно условно разделить на три глобальных самостоятельных направления - актуализация, автентизм и авангард. Наблюдается утверждение новой парадигмы, которая закпючается в повышении роли интеллектуального начала, в стремлении к изучению музыкального произедения в контексте эпохи, в очистке традиций исполнения от позднейших наслоений. Исполнительский тип аутентичного направления ставит задачу максимально точно соответствовать представлениям композиторов прошлого, воспроизводить принятые в разные исторические времена нормы и традиции. Из-за того, что человек осознает потерю своей целостности, традиционные формы искусства претерпевают трансформации и разрушения, которые вызвали потребность обращения к культуре барокко. Рецепция культуры барокко способствует восстановлению культурной идентичности, предостерегает от поликультурной фрагментарности, создает условия для налаживания связей между культурными эпохами. Эстетика барокко превращается в один из определяющих маркеров массовой культуры.

Ключевые слова: музыка, культура, исторически информированное исполнительство, аутентизм, интерпретация. 